Article

\title{
Does Fiscal Policy Promote Third-Party Environmental Pollution Control in China? An Evolutionary Game Theoretical Approach
}

\author{
Caihua Zhou ${ }^{1,2, *}$, Hualin Xie ${ }^{1}$ and Xinmin Zhang ${ }^{1}$ \\ 1 Institute of Ecological Civilization, Jiangxi University of Finance and Economics, Nanchang 330013, China \\ 2 School of Public Finance and Public Administration, Jiangxi University of Finance and Economics, \\ Nanchang 330013, China \\ * Correspondence: audrey0515@163.com
}

Received: 9 June 2019; Accepted: 13 August 2019; Published: 16 August 2019

check for updates

\begin{abstract}
To promote third-party environmental pollution control in China, it is necessary to dissect the mechanism of fiscal policy in third-party environmental pollution control. This study first discusses the acting paths of fiscal policies on third-party environmental pollution control in theory. A tripartite evolutionary game model involving the local government, the polluting enterprise, and the third-party enterprise is established. The replicator dynamics, evolutionary stability strategies, and numerical simulation of the behavior of the three participants are analyzed to further study the acting mechanism of fiscal policy in third-party environmental pollution control. In addition, the influences of other parameters on the implementation of third-party environmental pollution control are evaluated. The results show that the behaviors of the local government, the polluting enterprise, and the third-party enterprise influence each other. Furthermore, strengthening the relevant fiscal policy, reducing the risks of the polluting enterprise and third-party enterprise, and improving the benefit to the local government are conducive to promoting third-party environmental pollution control in China. Based on these results, this study proposes the following policy implications: formulating fiscal policies for third-party environmental pollution control, implementing fiscal policies in a dynamic and progressive manner, improving the market mechanism of third-party environmental pollution control, and strengthening the environmental performance assessment of the local government.
\end{abstract}

Keywords: environmental pollution; third-party control; fiscal policy; evolutionary game

\section{Introduction}

China has received high attention from countries worldwide due to its rapid economic growth, industrialization, and urbanization. However, the frequent occurrences of ecological damage and environmental pollution show that China is facing great resource and environment constraints [1-3]. The combination of environmental pollution control and economic development has become the "new normal" in China's modernization process [4-6].

As environmental issues have the characteristics of externality, polluters cannot control environmental pollution well; thus, the government needs to participate in environmental governance directly [7]. Some scholars believe that the fiscal competition among local governments [8] promotes environmental protection under certain conditions [9-11], while other scholars believe that such competition leads to a worse environmental quality $[12,13]$. To obtain short-term economic competitive advantages among regions [14,15], i.e., expanding the tax base and increasing tax revenue, local governments may ignore the environment and relax the supervision and governance of the environment [16-19]. In addition, the unclear division of environmental protection powers between 
the central government and the local government leads to the duplication or absence of environmental protection measures [20]. Therefore, government failure could also result in a low level and low efficiency of environmental pollution control [21,22].

Due to changes in government functions and the enrichment of environmental pollution control methods, the market plays an increasingly important role in environmental pollution control [23,24]. China proposed third-party environmental pollution control in 2013 for the first time [25]. In this new mode of environmental pollution control, polluters pay environmental service enterprises to conduct pollution treatment according to a contract [26] similar to the environmental service contract (ESC). To date, much progress has been made in third-party environmental pollution control in China. However, there are still various problems in practice, such as insufficient market momentum, unclear authority and responsibility, inefficiency regulation, lack of supporting policies, etc. [27-29].

The theoretical basis for using fiscal policies to intervene in environmental protection was first proposed by Western economists from different perspectives, including the externality theory and the public goods theory [30-32]. Fiscal policies have played an important role in the practice of environmental pollution control [33,34]. With the expansion of the subjects in environmental pollution control to the government, the market and the society, the incentive and guiding role of fiscal policies is increasingly indispensable [35-37]. Similarly, to promote third-party environmental pollution control, China decided to reduce the corporate income tax rate of third-party enterprises by 15\% during the 2019-2021 period [38]. Additional fiscal policies have also been suggested, such as government environmental procurement, value-added tax, income tax and other preferential tax policies, and environmental service industry investment funds [29,39-42].

The evolutionary game method has been widely used in economics research, including environmental governance $[43,44]$. Some scholars have analyzed the behaviors of subjects in different environmental pollution control methods using evolutionary game method. For example, Zhang and $\mathrm{Li}$ (2018) established an evolutionary game model of local governments on haze cooperative control. Through the analysis of dynamic evolution path and evolutionary stability strategy, the results showed that the heterogeneity of local government was not conducive to the formation and stability of the cooperative control model, while the administrative penalties imposed by the superior government was just the opposite [45]. Jiang et al. (2019) proposed an evolutionary game model of government environmental regulation including polluting enterprises, local governments and central governments in China. The environmental pollution control behaviors of the three participants were analyzed under the background of fiscal decentralization [46]. There are also researches on third-party environmental pollution control using evolutionary game method. For example, Du et al. (2015) constructed an evolutionary model between third-party pollution control enterprises and governments under different parameters. According to the analysis results, policy suggestions were put forward to achieve the ideal steady state [47]. Xu et al. (2018) established a tripartite evolutionary game model involving governments, environmental service enterprises and polluting enterprises. The key influence factors of third-party environmental pollution control were discussed, and relevant policy recommendations were put forward according to the conclusions [48].

Some scholars have analyzed the acting mechanism of various policies including fiscal policies on environmental pollution control using evolutionary game method. For example, Duan et al. (2016) established tripartite evolutionary game models of government-enterprise-social based on system dynamics. By changing the "Reward for no pollution discharge" and other government environmental regulation strategies, the actions and the data outputs were compared between the static punishment model and the dynamic punishment model [49]. Xie et al. (2018) constructed evolutionary game models involving the government and peasant under different subsidy strategies, as well as an evolutionary game model between the central and local government in the process of protecting cultivated land. Through simulation analysis, the influences of external factors on the strategies are compared under different conditions [50]. Long et al. (2019) established a tripartite evolutionary game model involving governments, consumers and enterprises in the take-out waste recycling industry, 
and explored the evolutionary equilibrium and the main driving factors including the subsidy to consumers and enterprises [51]. There are also researches specifically on fiscal policies. For example, Liu et al. (2017) built an evolutionary game model between auto manufacturers and governments to estimates the influence of governmental emission taxations and subsidies. By comparing the effects of various policy combinations, it was shown that a policy of dynamic taxations and static subsidies was more effective than other policies [52]. Chen and $\mathrm{Hu}$ (2018) developed an evolutionary game theory model between governments and manufacturers based on different combinations of carbon taxes and subsidies. It turned out that the bilateral dynamic tax and subsidy mechanism was more effective [53].

Based on the above mentioned points, it can be seen that most studies have adopted an evolutionary game involving two parties. Few studies have adopted a tripartite evolutionary game. Studies investigating third-party environmental pollution control by the evolutionary game method are rare. Research investigating third-party environmental pollution control under fiscal policy by a tripartite evolutionary game model has not been performed. This study carries out the relevant research, contributing by offering policy implications to promote third-party environmental pollution control in China. This paper answers the following questions:

(1) Could the implementation of fiscal policies promote third-party environmental pollution control? How do the actions of the government, the polluting enterprise and the third-party enterprise interact?

(2) What other important factors influence the behavior of the government, the polluting enterprise and the third-party enterprise? How do these factors promote third-party environmental pollution control?

(3) What fiscal policies and suggestions could be proposed to promote third-party environmental pollution control in China?

The structure of this paper is organized as follows. Section 2 introduces the theory and methodology. Section 3 describes the modeling according to the basic assumptions. Section 4 analyzes the evolutionary path and numerical simulation. Section 5 explores other influencing parameters. Finally, the conclusions and policy implications are summarized in Section 6.

\section{Theory and Methodology}

\subsection{Acting Paths of Fiscal Policies on Third-Party Environmental Pollution Control}

(1) Acting paths of fiscal expenditure policies

As shown in Figure 1, fiscal subsidies may be transferred as payments from the central government to the local government, from the central government to the polluting enterprise and the third-party enterprise, or from the local government to the polluting enterprise and the third-party enterprise. The central government and the local government implement fiscal subsidy policies for the third-party enterprise to reduce its operating costs and increase the supply of third-party pollution control, as shown in Figure 2a. The central government implements the transfer payment policy to the local government, which chooses the third-party control to reduce the associated costs and thereby increase the local government's demand for third-party control, as shown in Figure 2b. Similarly, the local government offers subsidies to the polluting enterprise, which chooses the third-party control to reduce costs and improve the enterprise's demand for third-party governance, as shown in Figure $2 \mathrm{~b}$.

(2) Acting paths of fiscal revenue policies

As shown in Figure 1, preferential tax policies may be implemented by the central government and the local government to encourage the polluting enterprise and the third-party enterprise to engage in third-party pollution control. The central government and the local government implement preferential tax policies for the third-party enterprise to reduce operating costs and thereby improve the supply of third-party pollution control, as shown in Figure 2a. The central government and local 
government implement preferential tax policies for the polluting enterprise, which chooses third-party control to reduce costs and improve the enterprise's demand for third-party control, as shown in Figure 2b.

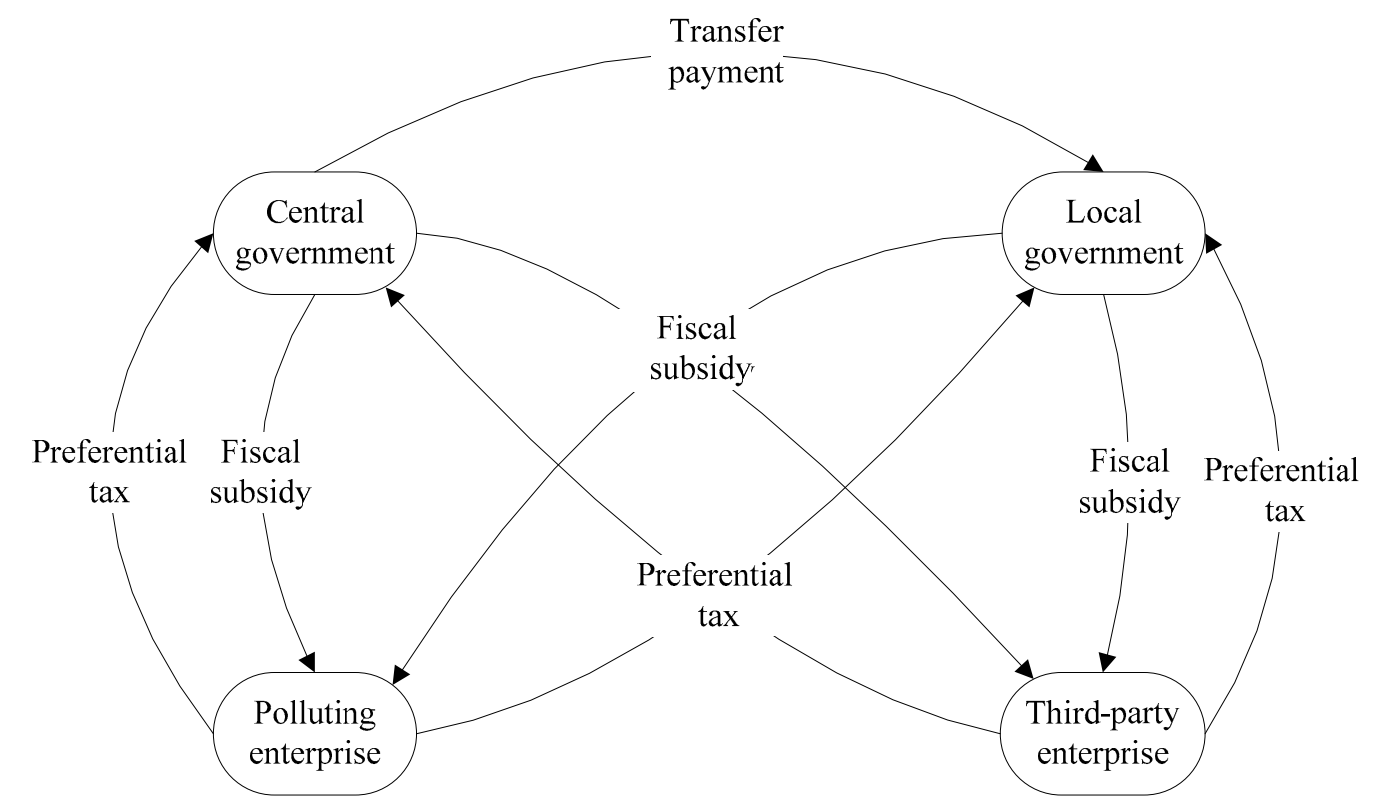

Figure 1. Acting paths of fiscal policies for third-party environmental pollution control.

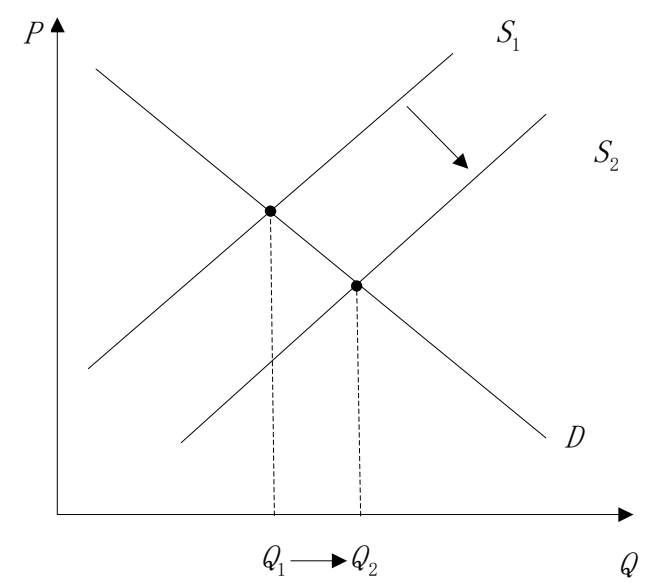

(a)

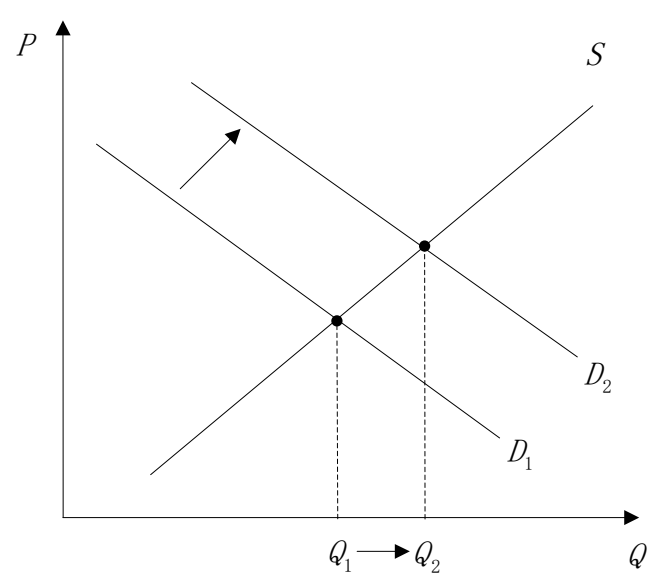

(b)

Figure 2. Demand and supply of third-party environmental pollution control in different conditions: (a) supply increasing; (b) demand increasing.

\subsection{Research Methodology}

Evolutionary game theory combines game theory and a dynamic evolutionary analysis by considering that at a stable equilibrium in the economy, an economic subject with limited rationality engages in continuous imitation and learning of favorable strategies to finally reach a stable strategy, i.e., an evolutionary stable strategy (ESS) [54]. Replication dynamics refers to a dynamic differential equation that describes the proportion of a particular strategy adopted in a population as follows:

$$
\mathrm{F}(\mathrm{x})=\mathrm{dx} / \mathrm{dt}=\mathrm{x}\left(\mathrm{U}_{\mathrm{S}}-\overline{\mathrm{U}}\right)
$$

where $\mathrm{dx} / \mathrm{dt}$ is the rate of change in the proportion of game participants adopting strategy $\mathrm{S}$ over time. The value $x$ is the proportion of game participants adopting strategy $S . U_{S}$ is the expected return 
of a game participant adopting strategy S. $\overline{\mathrm{U}}$ is the average expected return of the game participant. The stability points of the ESS should have the following properties: if one player deviates from stable point $x^{*}$ due to an accidental error, the replication dynamic will still return $x$ to $x^{*}$. Mathematically, when the disturbance makes $x$ lower than $x^{*}, F(x)=d x / d t$ must be greater than 0 ; thus, $t \uparrow$, then, $x \uparrow$ to return $x$ to $x^{*}$; when the disturbance makes $x$ higher than $x^{*}, F(x)=d x / d t$ must be less than 0 ; thus, $t \uparrow$, then $x \downarrow$ to return $x$ to $x^{*}$.

According to Figure 3, when the evolution reaches a stable state, the derivative of the differential equation of the replicator dynamics should be less than 0 , namely, $\mathrm{F}^{\prime}\left(\mathrm{x}^{*}\right)<0$.

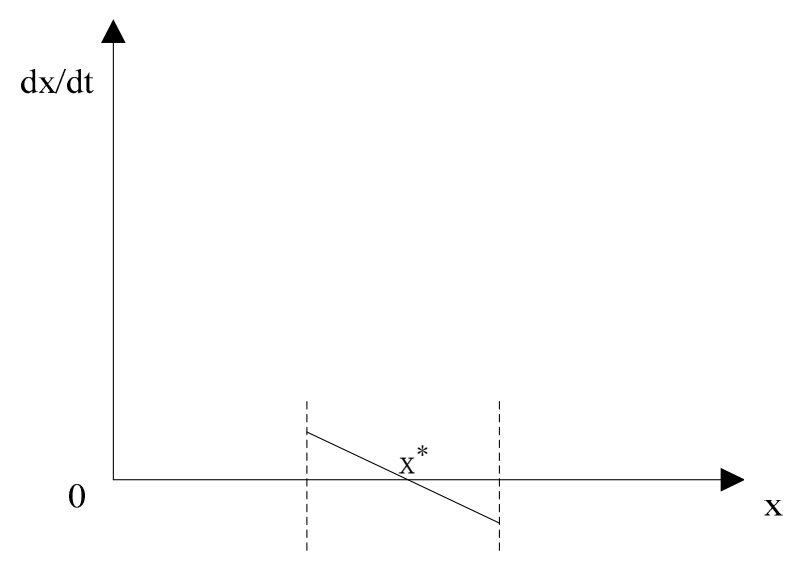

Figure 3. Conditions of the evolutionary stability strategy.

\section{Basic Assumptions and Modeling}

Third-party environmental pollution control includes the government's third-party control and enterprise's third-party control. The enterprise's third-party control in China has been implemented for a relatively short time, and the polluting enterprise and the third-party enterprise tend to be conservative in strategic choices. Therefore, it is necessary and urgent for the government to formulate and implement fiscal policies to promote the enterprise's third-party control. This study considers the case of the fiscal expenditure policy implemented by the local government for the enterprises' third-party control. As an indirect expenditure of the government, preferential tax policy is a type of fiscal expenditure. Thus, its function is shown in the analysis of the fiscal expenditure policy.

The game participants are as follows: the local government $G$, the polluting enterprise $P$, and the third-party enterprise $T$. The behavioral strategies are as follows: $S_{G}=\left\{S_{1}, S_{2}\right\}, S_{P}=\left\{S_{3}, S_{4}\right\}$, and $S_{T}=\left\{S_{5}, S_{6}\right\} . S_{1}$ indicates that the local government implements a fiscal expenditure policy for third-party environmental pollution control to the polluting enterprise and the third-party enterprise. $\mathrm{S}_{2}$ indicates that the local government does not implement a fiscal policy. $S_{3}$ indicates that the polluting enterprise accepts the fiscal policy and improves the demand for third-party control. $\mathrm{S}_{4}$ indicates that the polluting enterprise does not accept the fiscal policy. $S_{5}$ indicates that the third-party enterprise accepts the fiscal policy and improves the supply of third-party control. $S_{6}$ indicates that the third-party enterprise does not accept the fiscal policy.

The proportion of the adoption of behavioral strategies is as follows: during the initial stage of the game, the probability that the local government chooses $S_{1}$ is $x$, the probability that the polluting enterprise chooses $S_{3}$ is $y$, and the probability that the third-party enterprise chooses $S_{5}$ is $z$.

There are eight game strategy profiles among the three participants as follows:

$\left(\mathrm{S}_{1}, \mathrm{~S}_{3}, \mathrm{~S}_{5}\right),\left(\mathrm{S}_{1}, \mathrm{~S}_{3}, \mathrm{~S}_{6}\right),\left(\mathrm{S}_{1}, \mathrm{~S}_{4}, \mathrm{~S}_{5}\right),\left(\mathrm{S}_{1}, \mathrm{~S}_{4}, \mathrm{~S}_{6}\right),\left(\mathrm{S}_{2}, \mathrm{~S}_{3}, \mathrm{~S}_{5}\right),\left(\mathrm{S}_{2}, \mathrm{~S}_{3}, \mathrm{~S}_{6}\right),\left(\mathrm{S}_{2}, \mathrm{~S}_{4}, \mathrm{~S}_{5}\right)$, and $\left(\mathrm{S}_{2}, \mathrm{~S}_{4}, \mathrm{~S}_{6}\right)$.

The assumptions and implications of the return of the strategy portfolio are described as follows: 
(1) When the local government does not implement a fiscal expenditure policy and neither the polluting enterprise nor the third-party enterprise accepts the policy, the three subjects gain $\mathrm{U}, \mathrm{V}$, and $\mathrm{W}$, respectively.

(2) When the local government implements a fiscal expenditure policy for the polluting enterprise and the third-party enterprise with the intensity of $a_{1}$ and $a_{2}$, respectively, and the polluting enterprise and the third-party enterprise accept the fiscal policy and improve the demand and supply for third-party control, the three parties will gain $\mathrm{U}-\mathrm{a}_{1}-\mathrm{a}_{2}+\mathrm{M}, \mathrm{V}+\mathrm{a}_{1}+\mathrm{N}$, and $\mathrm{W}+\mathrm{a}_{2}+\mathrm{R}$, respectively. $\mathrm{M}, \mathrm{N}$, and $\mathrm{R}$ represent the benefits that the local government, the polluting enterprise and the third-party enterprise obtained from the third-party control. For example, $\mathrm{M}$ represents a higher tax revenue, reduced regulatory costs and improved social welfare; $\mathrm{N}$ represents a reduction in the pollution control cost and improvement in enterprise competitiveness; and $\mathrm{R}$ represents a higher economic benefit or technological progress.

(3) When the local government implements a fiscal expenditure policy, the polluting enterprise accepts the fiscal policy and improves the demand for third-party control, and the third-party enterprise accepts the fiscal subsidy without improving the supply for third-party control, the benefit to the local government is $U-a_{1}-a_{2}$, the benefit to the polluting enterprise is $V+a_{1}-b$ under the assumption that the search risk of the polluting enterprise increasing the demand for third-party control is $b$, and the benefit to the third-party enterprise increases to $W+a_{2}$.

(4) When the local government implements a fiscal expenditure policy for third-party environmental pollution control, the third-party enterprise accepts the fiscal policy and improves the supply for third-party control, and the polluting enterprise accepts the fiscal subsidy without improving the demand for third-party control, the benefit to the local government is $U-a_{1}-a_{2}$, the benefit to the polluting enterprise increases to $\mathrm{V}+\mathrm{a}_{1}$, and the benefit to the third-party enterprise is $\mathrm{W}+\mathrm{a}_{2}-\mathrm{c}$ under the assumption that the risk the third-party enterprise incurs when increasing the supply of third-party control is c.

(5) When the local government implements a fiscal expenditure policy and neither the polluting enterprise nor the third-party enterprise accepts the policy, the three parties will gain $U-a_{1}-a_{2}$, $\mathrm{V}+\mathrm{a}_{1}$, and $\mathrm{W}+\mathrm{a}_{2}$, respectively.

(6) When the local government does not implement a fiscal expenditure policy but the polluting enterprise and third-party enterprise believe that the government will implement the fiscal policy and accordingly improve the demand and supply for third-party control, the three parties will gain $\mathrm{U}+\mathrm{m}, \mathrm{V}+\mathrm{n}$, and $\mathrm{W}+\mathrm{r}$, respectively. Simultaneously, the trading volume of the third-party control market is lower than that of the fiscal policy implementation. The revenue increment of the three parties should be lower than the benefit when the fiscal policy is implemented, i.e., $\mathrm{M}>\mathrm{m}, \mathrm{N}>\mathrm{n}$, and $\mathrm{R}>\mathrm{r}$.

(7) When the local government does not implement a fiscal expenditure policy and only the polluting enterprise believes that the government will implement a fiscal policy and chooses third-party control, the benefit to the local government is $U$, the benefit to the polluting enterprise is $V-b$, and the benefit to the third-party enterprise is $\mathrm{W}$.

(8) When the local government does not implement a fiscal expenditure policy and only the third-party enterprise believes that the government will implement a fiscal policy and accordingly improves the supply for third-party control, the benefit to the local government is $U$, the benefit to the polluting enterprise is $\mathrm{V}$, and the benefit to the third-party enterprise is $\mathrm{W}-\mathrm{c}$.

(9) Suppose that $a_{1}, a_{2}, M, N, R, m, n, r, b, c>0, U>a_{1}+a_{2}, V>b, W>c, x, y, z \in[0,1]$. Since fiscal expenditure plays an expansionary role in the GDP, increasing the fiscal expenditure can expand the aggregate demand with a multiplier greater than 1 . In the long-term, third-party environmental pollution control will yield increasing taxes, reduce the regulatory costs and increase social welfare for the local government, i.e., $\mathrm{M}=\left(\mathrm{a}_{1}+\mathrm{a}_{2}\right)^{\mathrm{k}},\left(\mathrm{a}_{1}+\mathrm{a}_{2}\right)>1, \mathrm{k}>1$. 
Figure 4 shows the revenue corresponding to the eight strategy combinations in the tripartite game tree of the local government, the polluting enterprise and the third-party enterprise.

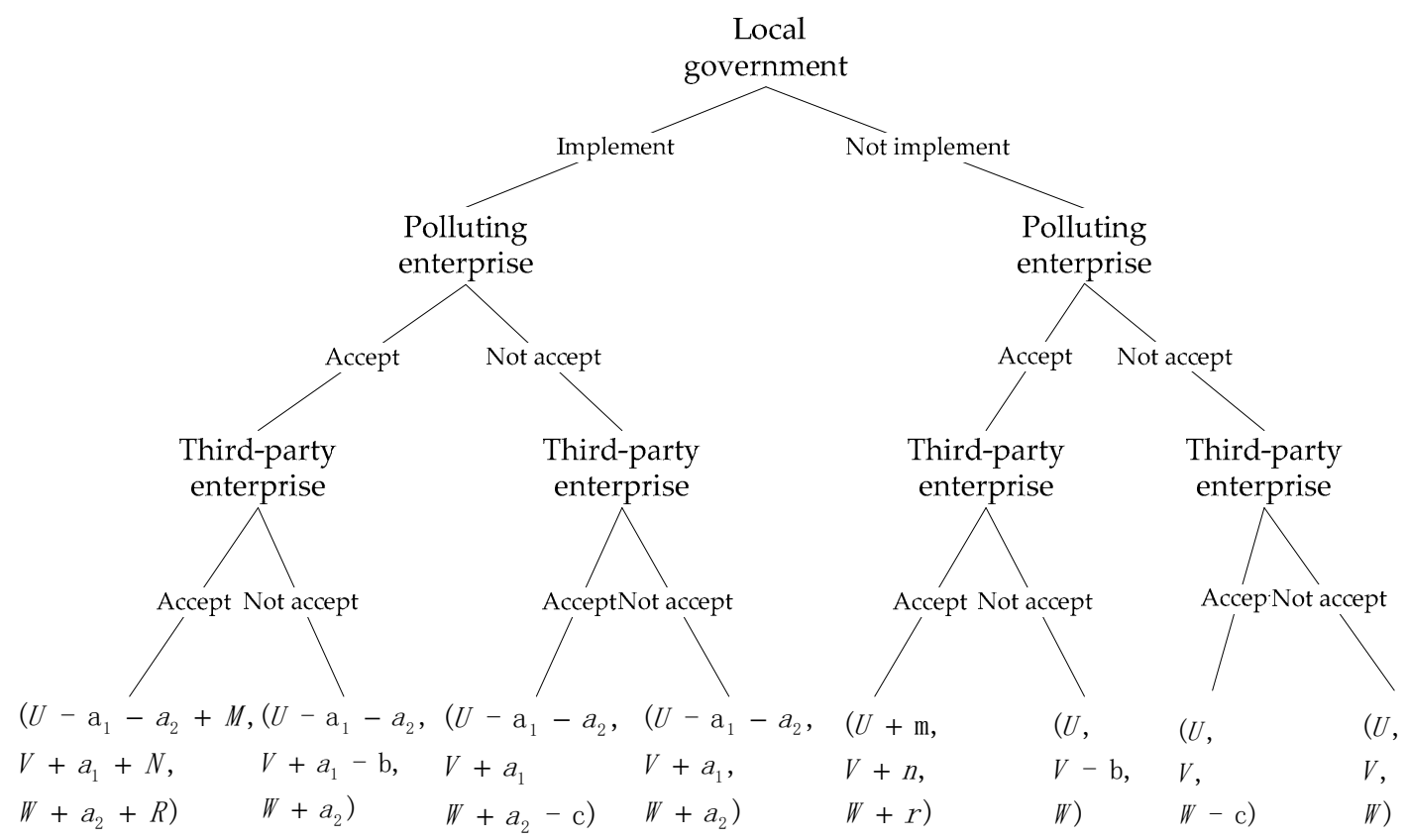

Figure 4. Tripartite game tree of the local government, polluting enterprise and third-party enterprise.

\section{Evolutionary Path and Simulation Analysis}

\subsection{Replicator Dynamics Analysis}

(1) Analysis of the replicator dynamics of the local government's strategies

When the local government implements and does not implement a fiscal policy, the expected benefits are described as follows:

$$
\begin{gathered}
\mathrm{U}_{\mathrm{GS}_{1}}=y z \mathrm{U}-\mathrm{a}_{1}-\mathrm{a}_{2}+\mathrm{M}+\mathrm{y}(1-\mathrm{z})\left(\mathrm{U}-\mathrm{a}_{1}-\mathrm{a}_{2}\right)+(1-\mathrm{y}) \mathrm{z}\left(\mathrm{U}-\mathrm{a}_{1}-\mathrm{a}_{2}\right) \\
+(1-\mathrm{y})(1-\mathrm{z})\left(\mathrm{U}-\mathrm{a}_{1}-\mathrm{a}_{2}\right)=\mathrm{U}-\mathrm{a}_{1}-\mathrm{a}_{2}+\mathrm{yzM} \\
\mathrm{U}_{\mathrm{GS}_{2}}=\mathrm{yzU}+\mathrm{m}+\mathrm{y}(1-\mathrm{z}) \mathrm{U}+(1-\mathrm{y}) \mathrm{zU}+(1-\mathrm{y})(1-\mathrm{z}) \mathrm{U}=\mathrm{U}+\mathrm{yzm}
\end{gathered}
$$

Thus, the average expected revenue of the local government is expressed as follows:

$$
\overline{\mathrm{U}}_{\mathrm{G}}=\mathrm{xU}_{\mathrm{GS}_{1}}+(1-\mathrm{x}) \mathrm{U}_{\mathrm{GS}_{2}}
$$

The replicator dynamics equation when the local government implements a fiscal policy is described as follows:

$$
\mathrm{F}(\mathrm{x})=\mathrm{dx} / \mathrm{dt}=\mathrm{x}\left(\mathrm{U}_{\mathrm{GS}_{1}}-\overline{\mathrm{U}}_{\mathrm{C}}\right)=\mathrm{x}(1-\mathrm{x})\left[\mathrm{yz}(\mathrm{M}-\mathrm{m})-\left(\mathrm{a}_{1}+\mathrm{a}_{2}\right)\right]
$$

The stability of the evolution strategies of the local government is analyzed as follows:

A. When $\mathrm{z}=\frac{\mathrm{a}_{1}+\mathrm{a}_{2}}{\mathrm{y}(\mathrm{M}-\mathrm{m})}, \mathrm{F}(\mathrm{x}) \equiv 0$, suggesting that regardless of the proportion of the local government implementing the fiscal policy, the strategy will not change over time as shown in Figure 5a.

B. When $\mathrm{z} \neq \frac{\mathrm{a}_{1}+\mathrm{a}_{2}}{\mathrm{y}(\mathrm{M}-\mathrm{m})}$, let $\mathrm{F}(\mathrm{x})=0 ; \mathrm{x}=0$ and $\mathrm{x}=1$ are the two stability points of the local government.

The derivative of $\mathrm{F}(\mathrm{x})$ yields $\frac{\mathrm{dF}(\mathrm{x})}{\mathrm{dx}}=(1-2 \mathrm{x})\left[\mathrm{yz}(\mathrm{M}-\mathrm{m})-\left(\mathrm{a}_{1}+\mathrm{a}_{2}\right)\right]$. The different situations are analyzed as follows: 
a. When $\mathrm{z}>\frac{\mathrm{a}_{1}+\mathrm{a}_{2}}{\mathrm{y}(\mathrm{M}-\mathrm{m})},\left.\frac{\mathrm{dF}(\mathrm{x})}{\mathrm{dx}}\right|_{\mathrm{x}=1}<0,\left.\frac{\mathrm{dF}(\mathrm{x})}{\mathrm{dx}}\right|_{\mathrm{x}=0}>0$; thus, the equilibrium point is $\mathrm{x}=1$ as shown in Figure 5b;

b. When $\mathrm{z}<\frac{\mathrm{a}_{1}+\mathrm{a}_{2}}{\mathrm{y}(\mathrm{M}-\mathrm{m})},\left.\frac{\mathrm{dF}(\mathrm{x})}{\mathrm{dx}}\right|_{\mathrm{x}=1}>0,\left.\frac{\mathrm{dF}(\mathrm{x})}{\mathrm{dx}}\right|_{\mathrm{x}=0}<0$; thus, the equilibrium point is $\mathrm{x}=0$ as shown in Figure 5c.

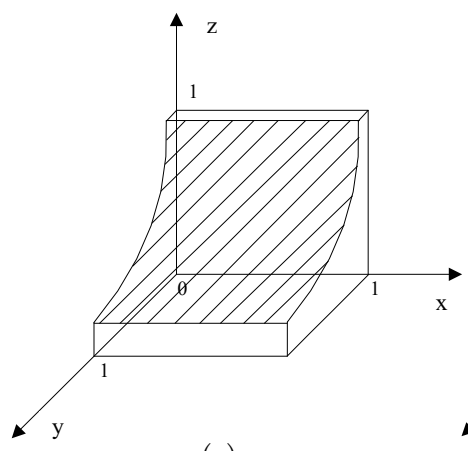

(a)

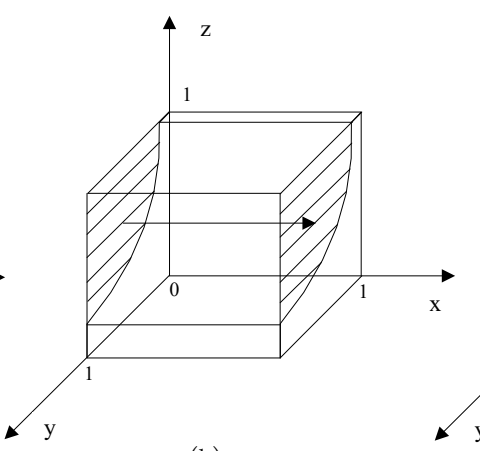

(b)

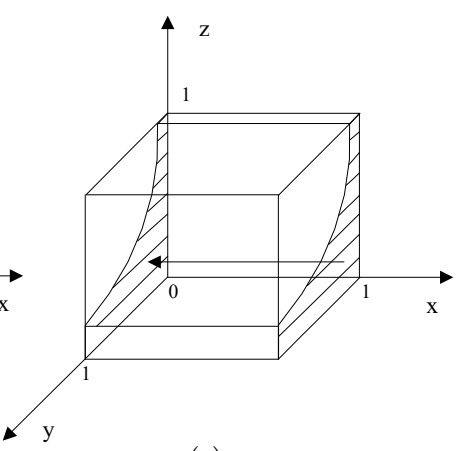

(c)

Figure 5. Duplicate phase diagrams of the local government in different conditions: $(a) z=\frac{a_{1}+a_{2}}{y(M-m)}$; (b) $\mathrm{z}>\frac{\mathrm{a}_{1}+\mathrm{a}_{2}}{\mathrm{y}(\mathrm{M}-\mathrm{m})} ;$ (c) $\mathrm{z}<\frac{\mathrm{a}_{1}+\mathrm{a}_{2}}{\mathrm{y}(\mathrm{M}-\mathrm{m})}$.

(2) Analysis of the replicator dynamics of the polluting enterprise's strategies

When the polluting enterprise chooses strategy $S_{3}$ and strategy $S_{4}$, the expected benefits are expressed as follows:

$$
\begin{gathered}
\mathrm{U}_{\mathrm{PS}_{3}}=\mathrm{xz}\left(\mathrm{V}+\mathrm{a}_{1}+\mathrm{N}\right)+\mathrm{x}(1-\mathrm{z})\left(\mathrm{V}+\mathrm{a}_{1}-\mathrm{b}\right)+(1-\mathrm{x}) \mathrm{z}(\mathrm{V}+\mathrm{n}) \\
+(1-\mathrm{x})(1-\mathrm{z})(\mathrm{V}-\mathrm{b}) \\
\mathrm{U}_{\mathrm{PS}_{4}}=\mathrm{xz}\left(\mathrm{V}+\mathrm{a}_{1}\right)+\mathrm{x}(1-\mathrm{z})\left(\mathrm{V}+\mathrm{a}_{1}\right)+(1-\mathrm{x}) \mathrm{zV}+(1-\mathrm{x})(1-\mathrm{z}) \mathrm{V}
\end{gathered}
$$

Thus, the average expected revenue of the polluting enterprise is described as follows:

$$
\overline{\mathrm{U}}_{\mathrm{P}}=\mathrm{yU}_{\mathrm{PS}_{3}}+(1-\mathrm{y}) \mathrm{U}_{\mathrm{PS}_{4}}
$$

The replicator dynamics equation of the polluting enterprise's willingness to accept the fiscal policy and improve the demand for third-party control is described as follows:

$$
\mathrm{F}(\mathrm{y})=\mathrm{dy} / \mathrm{dt}=\mathrm{y}\left(\mathrm{U}_{\mathrm{PS}_{3}}-\overline{\mathrm{U}}_{\mathrm{P}}\right)=\mathrm{y}(1-\mathrm{y})[\mathrm{xz}(\mathrm{N}-\mathrm{n})+\mathrm{z}(\mathrm{n}+\mathrm{b})-\mathrm{b}]
$$

The stability of the evolution strategies of the polluting enterprise is analyzed as follows:

A. When $x=\frac{b}{z(N-n)}-\frac{n+b}{N-n}, F(y) \equiv 0$, suggesting that regardless of the proportion of the polluting enterprise choosing to accept the fiscal policy, the strategy will not change over time as shown in Figure 6a.

B. When $x \neq \frac{b}{z(N-n)}-\frac{n+b}{N-n}$, let $F(y)=0 ; y=0$ and $y=1$ are the two stability points of the polluting enterprise.

The derivative of $F(y)$ yields $\frac{d F(y)}{d y}=(1-2 y)[x z(N-n)+z(n+b)-b]$. The different situations are analyzed as follows:

a. When $x>\frac{b}{z(N-n)}-\frac{n+b}{N-n},\left.\frac{d F(y)}{d y}\right|_{y=1}<0,\left.\frac{d F(y)}{d y}\right|_{y=0}>0$; thus, the equilibrium point is $y=1$ as shown in Figure 6b;

b. When $x<\frac{b}{z(N-n)}-\frac{n+b}{N-n},\left.\frac{d F(y)}{d y}\right|_{y=1}>0,\left.\frac{d F(y)}{d y}\right|_{y=0}<0$; thus, the equilibrium point is $y=0$ as shown in Figure 6c. 


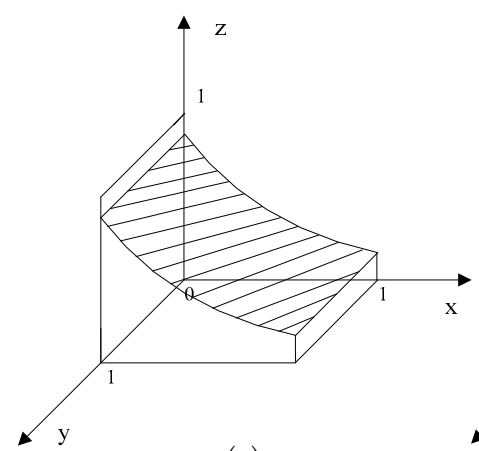

(a)

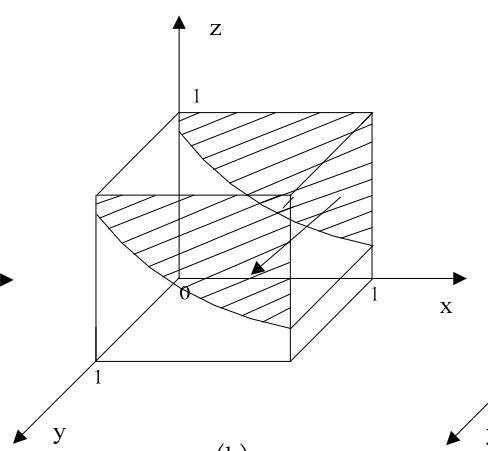

(b)

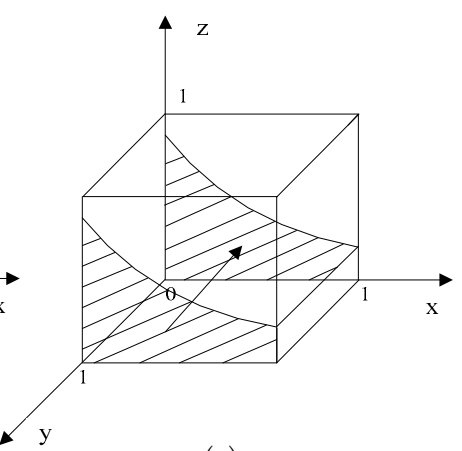

(c)

Figure 6. Duplicate phase diagrams of the polluting enterprise in different conditions: (a) $x=$ $\frac{\mathrm{b}}{\mathrm{z}(\mathrm{N}-\mathrm{n})}-\frac{\mathrm{n}+\mathrm{b}}{\mathrm{N}-\mathrm{n}} ;(\mathrm{b}) \mathrm{x}>\frac{\mathrm{b}}{\mathrm{z}(\mathrm{N}-\mathrm{n})}-\frac{\mathrm{n}+\mathrm{b}}{\mathrm{N}-\mathrm{n}} ;(\mathrm{c}) \mathrm{x}<\frac{\mathrm{b}}{\mathrm{z}(\mathrm{N}-\mathrm{n})}-\frac{\mathrm{n}+\mathrm{b}}{\mathrm{N}-\mathrm{n}}$.

(3) Analysis of the replicator dynamics of the third-party enterprise's strategies

When the third-party enterprise chooses strategy $S_{5}$ and strategy $S_{6}$, the expected benefits are described as follows:

$$
\begin{gathered}
\mathrm{U}_{\mathrm{TS}_{5}}=\mathrm{xy}\left(\mathrm{W}+\mathrm{a}_{2}+\mathrm{R}\right)+\mathrm{x}(1-\mathrm{y})\left(\mathrm{W}+\mathrm{a}_{2}-\mathrm{c}\right)+(1-\mathrm{x}) \mathrm{y}(\mathrm{W}+\mathrm{r})+(1-\mathrm{x})(1-\mathrm{y})(\mathrm{W}-\mathrm{c}) \\
\mathrm{U}_{\mathrm{TS}_{6}}=\mathrm{xy}\left(\mathrm{W}+\mathrm{a}_{2}\right)+\mathrm{x}(1-\mathrm{y})\left(\mathrm{W}+\mathrm{a}_{2}\right)+(1-\mathrm{x}) \mathrm{yW}+(1-\mathrm{x})(1-\mathrm{y}) \mathrm{W}
\end{gathered}
$$

Thus, the average expected revenue of the third-party enterprise is expressed as follows:

$$
\overline{\mathrm{U}}_{\mathrm{T}}=\mathrm{zU}_{\mathrm{TS}_{5}}+(1-\mathrm{z}) \mathrm{U}_{\mathrm{TS}_{6}}
$$

The replicator dynamics equation of the third-party enterprise's willingness to accept the fiscal policy and improve the supply for third-party control is expressed as follows:

$$
\mathrm{F}(\mathrm{z})=\mathrm{dz} / \mathrm{dt}=\mathrm{z}\left(\mathrm{U}_{\mathrm{TS}_{5}}-\overline{\mathrm{U}}_{\mathrm{T}}\right)=\mathrm{z}(1-\mathrm{z})[\mathrm{xy}(\mathrm{R}-\mathrm{r})+\mathrm{y}(\mathrm{r}+\mathrm{c})-\mathrm{c}]
$$

The stability of the evolution strategies of the third-party enterprise is analyzed as follows:

A. When $x=\frac{c}{y(R-r)}-\frac{r+c}{R-r}, F(z) \equiv 0$, suggesting that regardless of the proportion of the third-party enterprise choosing to accept the fiscal policy, the strategy will not change over time as shown in Figure 7a.

B. When $x \neq \frac{c}{y(R-r)}-\frac{r+c}{R-r}$, let $F(z)=0 ; z=0$ and $z=1$ are the two stability points of the third-party enterprise.

The derivative of $F(z)$ yields $\frac{d F(z)}{d z}=(1-2 z)[x y(R-r)+y(r+c)-c]$. The different situations are analyzed as follows:

a. When $\mathrm{x}>\frac{\mathrm{c}}{\mathrm{y}(\mathrm{R}-\mathrm{r})}-\frac{\mathrm{r}+\mathrm{c}}{\mathrm{R}-\mathrm{r}},\left.\frac{\mathrm{dF}(\mathrm{z})}{\mathrm{dz}}\right|_{\mathrm{z}=1}<0,\left.\frac{\mathrm{dF}(\mathrm{z})}{\mathrm{dz}}\right|_{\mathrm{z}=0}>0$; thus, the equilibrium point is $\mathrm{z}=1$ as shown in Figure 7b;

b. When $x<\frac{c}{y(R-r)}-\frac{r+c}{R-r},\left.\frac{d F(z)}{d z}\right|_{z=1}>0,\left.\frac{d F(z)}{d z}\right|_{z=0}<0$; thus, the equilibrium point is $z=0$ as shown in Figure 7c. 


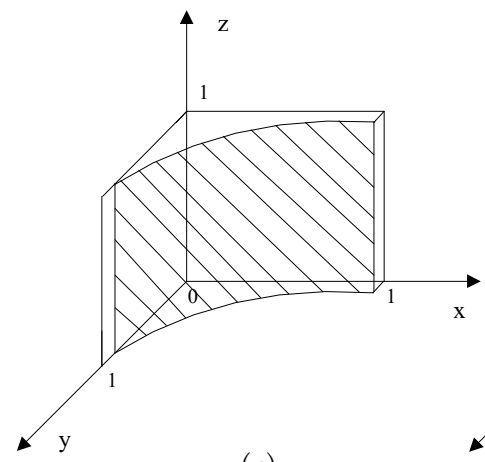

(a)

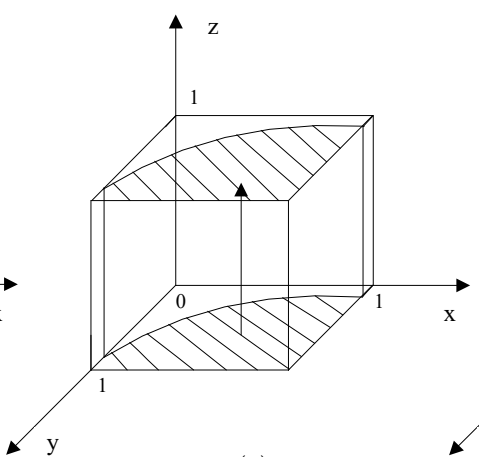

(b)

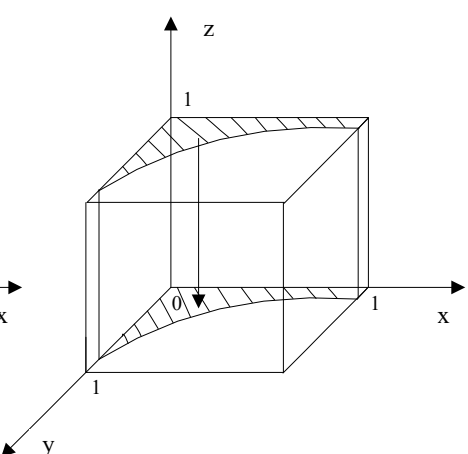

$(c)$

Figure 7. Duplicate phase diagrams of the third-party enterprise in different conditions: $(\mathbf{a}) \mathrm{x}=\frac{\mathrm{c}}{\mathrm{y}(\mathrm{R}-\mathrm{r})}-$ $\frac{\mathrm{r}+\mathrm{c}}{\mathrm{R}-\mathrm{r}} ;(\mathbf{b}) \mathrm{x}>\frac{\mathrm{c}}{\mathrm{y}(\mathrm{R}-\mathrm{r})}-\frac{\mathrm{r}+\mathrm{c}}{\mathrm{R}-\mathrm{r}} ;(\mathbf{c}) \mathrm{x}<\frac{\mathrm{c}}{\mathrm{y}(\mathrm{R}-\mathrm{r})}-\frac{\mathrm{r}+\mathrm{c}}{\mathrm{R}-\mathrm{r}}$.

\subsection{Stability of the Evolutionary Strategies Analysis}

The stability analysis of the strategy combinations of the local government, the polluting enterprise and the third-party enterprise can be carried out through the Jacobian matrix [55]. The Jacobian matrix in this paper is shown as follows:

$$
\left[\begin{array}{ccc}
(1-2 x)\left[y z(M-m)-\left(a_{1}+a_{2}\right)\right] & x z(1-x)(M-m) & x z(1-x)(M-m) \\
y z(1-y)(N-n) & (1-2 y)[x z(N-n)+z(n+b)-b] & y(1-y)[x(N-n)+(n+b)] \\
y z(1-z)(R-r) & z(1-z)[x(R-r)+(r+c)] & (1-2 z)[x y(R-r)+y(r+c)-c]
\end{array}\right]
$$

According to Lyapunov's first method [56], regarding the ESS, the characteristic root of its corresponding Jacobian matrix must be less than 0 . In Table 1 , the symbols shown in brackets indicate the positive and negative values of the eigenvalues.

Table 1. Stability of the equilibrium points.

\begin{tabular}{ccc}
\hline Equilibrium & Characteristic Roots and Symbols & Local Stability \\
\hline$(0,0,0)$ & $-\left(\mathrm{a}_{1}+\mathrm{a}_{2}\right)(-),-\mathrm{b}(-),-\mathrm{c}(-)$ & ESS \\
$(1,0,0)$ & $\left(\mathrm{a}_{1}+\mathrm{a}_{2}\right)(+),-\mathrm{b}(-),-\mathrm{c}(-)$ & Unstable \\
$(0,1,0)$ & $-\left(\mathrm{a}_{1}+\mathrm{a}_{2}\right)(-), \mathrm{b}(+), \mathrm{r}(+)$ & Unstable \\
$(0,0,1)$ & $-\left(\mathrm{a}_{1}+\mathrm{a}_{2}\right)(-), \mathrm{n}(+), \mathrm{c}(+)$ & Unstable \\
$(1,1,0)$ & $\left(\mathrm{a}_{1}+\mathrm{a}_{2}\right)(+), \mathrm{b}(+), \mathrm{R}(+)$ & Unstable \\
$(1,0,1)$ & $\left(\mathrm{a}_{1}+\mathrm{a}_{2}\right)(+), \mathrm{N}(+), \mathrm{c}(+)$ & Unstable \\
$(0,1,1)$ & $(\mathrm{M}-\mathrm{m})-\left(\mathrm{a}_{1}+\mathrm{a}_{2}\right)(+),-\mathrm{n}(-),-\mathrm{r}(-)$ & Unstable \\
$(1,1,1)$ & $\left(\mathrm{a}_{1}+\mathrm{a}_{2}\right)-(\mathrm{M}-\mathrm{m})(-),-\mathrm{N}(-),-\mathrm{R}(-)$ & ESS \\
\hline
\end{tabular}

By analyzing the strategic stability of each subject, we obtain the stability strategies of the tripartite evolutionary game. Of the eight equilibrium points, two equilibrium points have local stability. The ESSs are (implementation, acceptance, acceptance) and (non-implementation, non-acceptance, non-acceptance).

\subsection{Numerical Simulation}

To more directly show the evolutionary path of the system, the evolutionary game model is analyzed through a numerical simulation. According to the above assumptions, i.e., $\mathrm{M}>\mathrm{m}$, $\mathrm{N}>\mathrm{n}, \mathrm{R}>\mathrm{r}, \mathrm{M}=\left(\mathrm{a}_{1}+\mathrm{a}_{2}\right)^{\mathrm{k}},\left(\mathrm{a}_{1}+\mathrm{a}_{2}\right)>1$, and $\mathrm{k}>1$, this paper sets the initial values of the parameters as $\mathrm{a}_{1}=1, \mathrm{a}_{2}=1, \mathrm{M}=14, \mathrm{~N}=10, \mathrm{R}=11, \mathrm{~m}=4, \mathrm{n}=2, \mathrm{r}=3, \mathrm{~b}=3$, and $\mathrm{c}=5$.

(1) For the fixed $x$ initial value (e.g., $x=0.5)$ to achieve the ideal state of equilibrium, it needs to satisfy $A=y z(M-m)-\left(a_{1}+a_{2}\right)>0$. From the random initial value of $y$ and $z$, the evolution curve of $x\left(x=\frac{1}{e^{-A t}+1}\right)$ is shown in Figure 8. As shown, the different initial values of $y$ and $z$ have 
an impact on the convergence rate of $x$, but $x$ still monotonically increases and converges to 1 , indicating that the proportion of the local governments choosing the "implementation" strategy continues to increase over time until all local governments eventually choose "implementation".

(2) For the fixed $y$ initial value (e.g., $y=0.5)$ to achieve the ideal state of equilibrium, it needs to satisfy $B=x z(N-n)+z(n+b)-b>0$. From a random initial value of $x$ and $z$, the evolution curve of $y\left(y=\frac{1}{e^{-B t}+1}\right)$ is shown in Figure 9. As shown, the different initial values of $x$ and $z$ have an impact on the convergence rate of $y$, but y still monotonically increases and converges to 1 , indicating that the proportion of the polluting enterprises choosing the "acceptance" strategy continues to increase over time until all polluting enterprises eventually choose "acceptance".

(3) For the fixed $\mathrm{z}$ initial value (e.g., $\mathrm{z}=0.5$ ) to achieve the ideal state of equilibrium, it needs to satisfy $C=x y(R-r)+y(r+c)-c>0$. From a random initial value of $x$ and $y$, the evolution curve of $z\left(z=\frac{1}{e^{-C t}+1}\right)$ is shown in Figure 10. As shown, the different initial values of $x$ and $y$ have an impact on the convergence rate of $z$, but $y$ still monotonically increases and converges to 1 , indicating that the proportion of the third-party enterprises choosing the "acceptance" strategy continues to increase over time until all third-party enterprises eventually choose "acceptance".

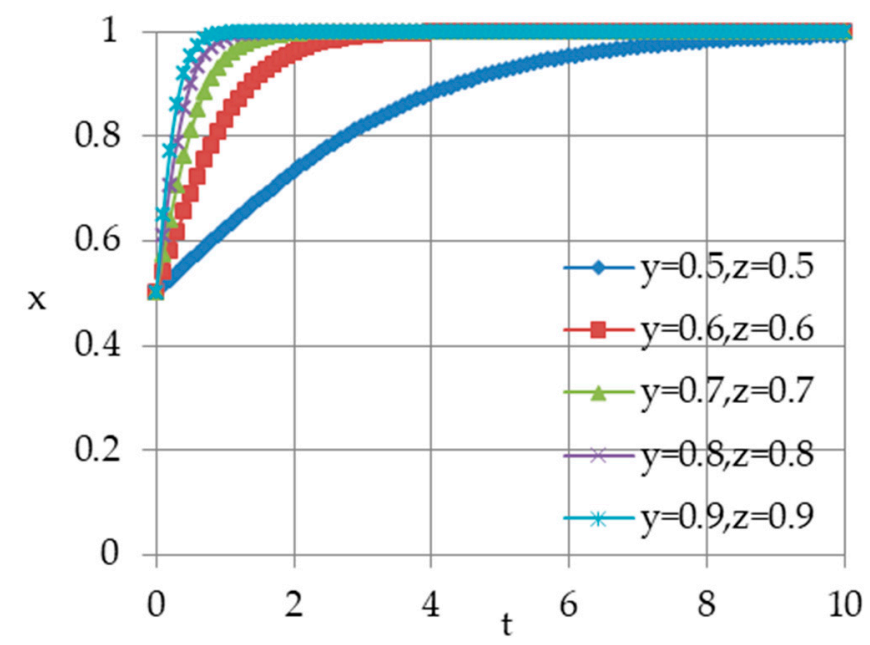

Figure 8. Evolution curve of the $\mathrm{x}$ value under different $\mathrm{y}$ and $\mathrm{z}$ values.

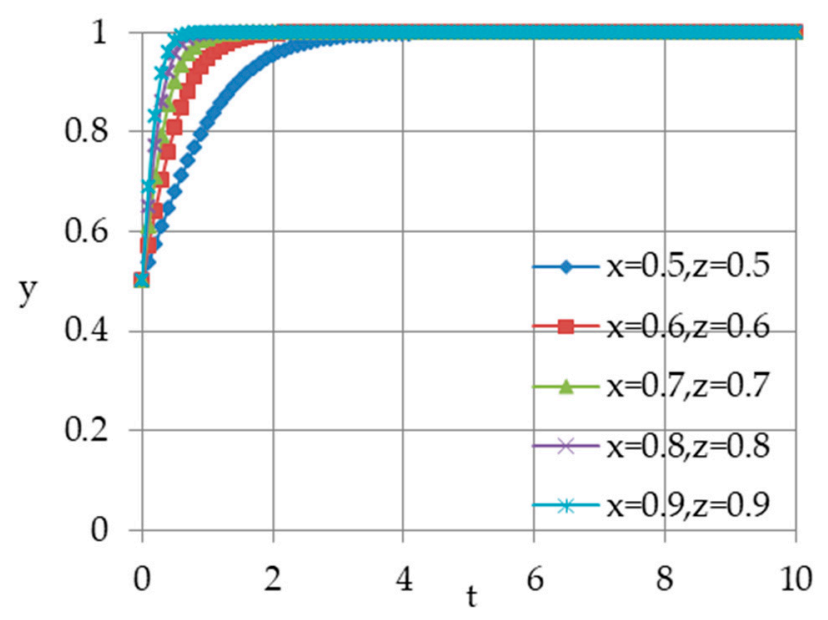

Figure 9. Evolution curve of the $y$ value under different $x$ and $z$ values. 


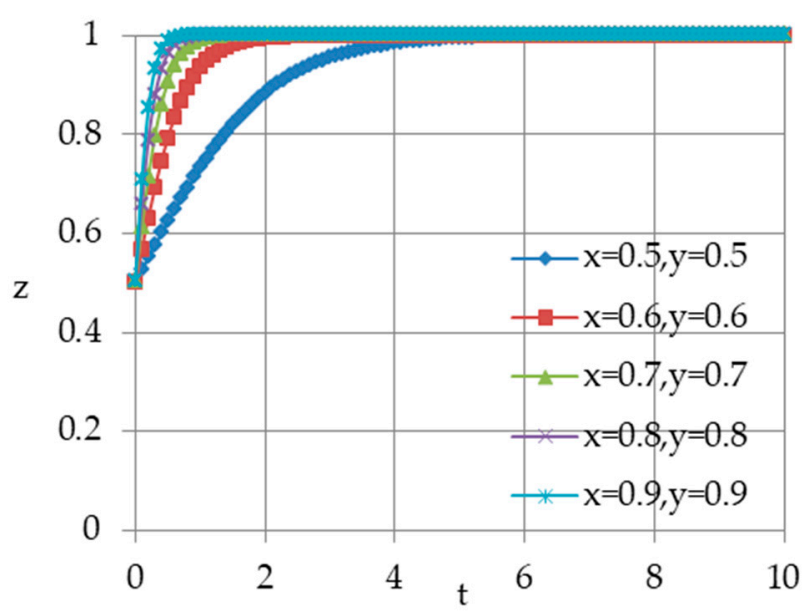

Figure 10. Evolution curve of the $\mathrm{z}$ value under different $\mathrm{x}$ and $\mathrm{y}$ values.

\section{Parameter Analysis}

In addition, the following equation set calculates a central point in the tripartite evolutionary game model of third-party environmental pollution control.

$$
\left\{\begin{array}{c}
x=\frac{b}{z(N-n)}-\frac{n+b}{N-n} \\
x=\frac{c}{y(R-r)}-\frac{r+c}{R-r} \\
z=\frac{a_{1}+a_{2}}{y(M-m)}
\end{array}\right.
$$

Assuming that $\mathrm{M}-\mathrm{m}=\Delta \mathrm{m}, \mathrm{N}-\mathrm{n}=\Delta \mathrm{n}, \mathrm{R}-\mathrm{r}=\Delta \mathrm{r}$, and $\mathrm{a}_{1}+\mathrm{a}_{2}=\mathrm{A}$, we can obtain the central point solution.

$$
\left\{\begin{aligned}
\mathrm{x}^{*} & =\frac{2 \mathrm{bc} \Delta \mathrm{m}}{-\mathrm{A}[\Delta \mathrm{n}(\mathrm{r}+\mathrm{c})-\Delta \mathrm{r}(\mathrm{n}+\mathrm{b})]+\sqrt{\mathrm{A}^{2}[\Delta \mathrm{n}(\mathrm{r}+\mathrm{c})-\Delta \mathrm{r}(\mathrm{n}+\mathrm{b})]^{2}+4 \mathrm{Abc} \Delta \mathrm{m} \Delta \mathrm{n} \Delta \mathrm{r}}}-\frac{\mathrm{r}+\mathrm{c}}{\Delta \mathrm{r}} \\
& =\frac{\mathrm{Ab}[\Delta \mathrm{n}(\mathrm{r}+\mathrm{c})-\Delta \mathrm{r}(\mathrm{n}+\mathrm{b})]+\sqrt{\mathrm{A}^{2}[\Delta \mathrm{n}(\mathrm{r}+\mathrm{c})-\Delta \mathrm{r}(\mathrm{n}+\mathrm{b})]^{2}+4 \mathrm{Abc} \Delta \mathrm{m} \Delta \mathrm{n} \Delta \mathrm{r}}}{-\sqrt{\mathrm{A}^{2}[\mathrm{~b}}}-\frac{\mathrm{n}}{\Delta \mathrm{n}(\mathrm{r}+\mathrm{c})-\Delta \mathrm{r}(\mathrm{n}+\mathrm{b})]^{2}+4 \mathrm{Abc} \Delta \mathrm{m} \Delta \mathrm{n} \Delta \mathrm{r}} \\
\mathrm{y}^{*} & =\frac{-\mathrm{A}[\Delta \mathrm{n}(\mathrm{r}+\mathrm{c})-\Delta \mathrm{r}(\mathrm{n}+\mathrm{b})]+\sqrt{2 \mathrm{~b} \Delta \mathrm{m} \Delta \mathrm{r}}}{2 \mathrm{c} \Delta \mathrm{m} \Delta \mathrm{n}} \\
\mathrm{z}^{*} & =\frac{\mathrm{A}[\Delta \mathrm{n}(\mathrm{r}+\mathrm{c})-\Delta \mathrm{r}(\mathrm{n}+\mathrm{b})]+\sqrt{\mathrm{A}^{2}[\Delta \mathrm{n}(\mathrm{r}+\mathrm{c})-\Delta \mathrm{r}(\mathrm{n}+\mathrm{b})]^{2}+4 \mathrm{Abc} \Delta \mathrm{m} \Delta \mathrm{n} \Delta \mathrm{r}}}{}
\end{aligned}\right.
$$

The central point solution shows that $x^{*}, y^{*}, z^{*}$ are all related to the parameters $\mathrm{a}_{1}, \mathrm{a}_{2}, \mathrm{~b}, \mathrm{c}, \mathrm{M}, \mathrm{N}, \mathrm{R}, \mathrm{m}, \mathrm{n}$, and $\mathrm{r}$. By solving a partial derivative of $\mathrm{x}^{*}, \mathrm{y}^{*}, \mathrm{z}^{*}$ with respect to parameters $N, R, m, n$, and $r$, it can be observed that the outcome is uncertain and that these parameters are not related to the fiscal policy; therefore, this paper does not discuss the influence of parameters $\mathrm{N}, \mathrm{R}, \mathrm{m}, \mathrm{n}$, and $\mathrm{r}$.

(1) Parameter $\mathrm{A}=\mathrm{a}_{1}+\mathrm{a}_{2}$ represents the fiscal expenditure policy formulated by the local government to encourage the polluting enterprise and third-party enterprise to choose third-party control. Solving a partial derivative of $x^{*}, y^{*}, z^{*}$ with respect to parameter A yields $\frac{\partial x^{*}}{\partial A}>0, \frac{\partial y^{*}}{\partial A}<0, \frac{\partial z^{*}}{\partial A}<0$. Therefore, the change in parameter $A$ will affect the decision-making behaviors of the three parties under the premise that the other parameters remain unchanged.

A. When $z>\frac{a_{1}+a_{2}}{y(M-m)}$, the local government will choose to implement the fiscal policy. Increasing $A$ leads to decreasing $\mathrm{y}^{*}$ and $\mathrm{z}^{*}$. Thus, $\mathrm{z}=\frac{\mathrm{a}_{1}+\mathrm{a}_{2}}{\mathrm{y}(\mathrm{M}-\mathrm{m})}$ moves inward, leading the probability of $z>\frac{a_{1}+a_{2}}{y(M-m)}$ to increase. Therefore, the possibility of the local government choosing to implement fiscal policy will increase. 
B. When $x>\frac{b}{z(N-n)}-\frac{n+b}{N-n}$, the polluting enterprise will accept the fiscal policy and choose third-party control. Increasing A leads to an increase in $x^{*}$ and a decrease in $z^{*}$. However, the proportion of the increase in $x^{*}$ and decrease in $z^{*}$ determines the immobility of $x=\frac{b}{z(N-n)}-\frac{n+b}{N-n}$. Therefore, the possibility of the polluting enterprise choosing to accept the fiscal policy will be unchanged.

C. When $x>\frac{c}{y(R-r)}-\frac{r+c}{R-r}$, the third-party enterprise will accept the fiscal policy and increase the supply for third-party control. Increasing A leads to an increase in $\mathrm{x}^{*}$ and a decrease in $\mathrm{y}^{*}$. However, the proportion of the increase in $\mathrm{x}^{*}$ and decrease in $\mathrm{y}^{*}$ determines the immobility of $x=\frac{c}{y(R-r)}-\frac{r+c}{R-r}$. Therefore, the possibility that the third-party enterprise chooses to accept the fiscal policy will be unchanged.

In conclusion, the increase in A is conducive to the convergence to the ideal ESS (implementation, acceptance, acceptance). The decrease in A is not conducive to the convergence to the ideal ESS. Therefore, the implementation of the fiscal policy for third-party environmental pollution control is conducive to promoting third-party control.

(2) Parameter b represents the risk faced by the polluting enterprise when choosing third-party control without expanding the supply of third-party enterprises. Solving a partial derivative of $x^{*}, y^{*}, z^{*}$ with respect to parameter $b$ yields $\frac{\partial x^{*}}{\partial b}>0, \frac{\partial y^{*}}{\partial b}<0, \frac{\partial z^{*}}{\partial b}>0$. Therefore, the change in parameter $b$ will affect the decision-making behaviors of the three parties under the premise that the other parameters remain unchanged.

A. When $z>\frac{a_{1}+a_{2}}{y(M-m)}$, the local government will choose to implement the fiscal policy. Increasing $\mathrm{b}$ leads to a decrease in $\mathrm{y}^{*}$ and an increase in $\mathrm{z}^{*}$. However, the proportion of the decrease in $y^{*}$ and increase in $z^{*}$ determines the immobility of $z=\frac{a_{1}+a_{2}}{y(M-m)}$. Therefore, the possibility of the local government choosing to implement the fiscal policy will increase.

B. When $x>\frac{b}{z(N-n)}-\frac{n+b}{N-n}$, the polluting enterprise will accept the fiscal policy and choose third-party control. Increasing $b$ leads to increases in $x^{*}$ and $z^{*}$. Thus, $x=\frac{b}{z(N-n)}-\frac{n+b}{N-n}$ moves outward, leading to the probability that $x=\frac{b}{z(N-n)}-\frac{n+b}{N-n}$ will decrease. Therefore, the possibility of the polluting enterprise choosing to accept the fiscal policy will decrease.

C. When $x>\frac{c}{y(R-r)}-\frac{r+c}{R-r}$, the third-party enterprise will accept the fiscal policy and increase the supply for third-party control. Increasing $b$ leads to an increase in $x^{*}$ and a decrease in $\mathrm{y}^{*}$. However, the proportion of the increase in $\mathrm{x}^{*}$ and decrease in $\mathrm{y}^{*}$ determines the immobility of $x=\frac{c}{y(R-r)}-\frac{r+c}{R-r}$. Therefore, the possibility that the third-party enterprise chooses to accept the fiscal policy will be unchanged.

In conclusion, the increase in $b$ is not conducive to the convergence to the ideal ESS (implementation, acceptance, acceptance). The decrease in $\mathrm{b}$ is conducive to the convergence to the ideal ESS. Therefore, reducing the risk of the polluting enterprise is conducive to promoting third-party control.

(3) Parameter $\mathrm{c}$ represents the risk faced by the third-party enterprise when expanding the supply of third-party control without expanding the demand. Solving a partial derivative of $x^{*}, y^{*}, z^{*}$ with respect to parameter c yields $\frac{\partial x^{*}}{\partial c}>0, \frac{\partial y^{*}}{\partial c}>0, \frac{\partial z^{*}}{\partial c}<0$. Therefore, the change in parameter $b$ will affect the decision-making behaviors of the three parties under the premise that the other parameters remain unchanged.

A. When $z>\frac{a_{1}+a_{2}}{y(M-m)}$, the local government will choose to implement the fiscal policy. The change in $c$ does not affect the position of $z=\frac{a_{1}+a_{2}}{y(M-m)}$. Therefore, the possibility that the local government chooses to implement the fiscal policy will be unchanged. 
B. When $x>\frac{b}{z(N-n)}-\frac{n+b}{N-n}$, the polluting enterprise will accept the fiscal policy and choose third-party control. The change in c does not affect the position of $x=\frac{b}{z(N-n)}-\frac{n+b}{N-n}$. Therefore, the possibility of the polluting enterprise choosing to accept the fiscal policy will be unchanged.

C. When $x>\frac{c}{y(R-r)}-\frac{r+c}{R-r}$, the third-party enterprise will accept the fiscal policy and increase the supply for third-party control. Increasing $c$ leads to increases in $x^{*}$ and $y^{*}$. Thus, $x>\frac{c}{y(R-r)}-\frac{r+c}{R-r}$ moves outward, leading the probability of $x>\frac{c}{y(R-r)}-\frac{r+c}{R-r}$ to decrease. Therefore, the possibility of the third-party enterprise choosing to accept the fiscal policy will decrease.

In conclusion, the increase in c is not conducive to the convergence to the ideal ESS (implementation, acceptance, acceptance). The decrease in $\mathrm{c}$ is conducive to the convergence to the ideal ESS. Therefore, reducing the risk of the third-party enterprise is conducive to promoting third-party control.

(4) Parameter M represents the local government's benefits when implementing the fiscal policy and when the polluting enterprise and the third-party enterprise expand the demand and supply of third-party control. Solving a partial derivative of $\mathrm{x}^{*}, \mathrm{y}^{*}, \mathrm{z}^{*}$ with respect to parameter $\mathrm{M}$ yields $\frac{\partial x^{*}}{\partial M}>0, \frac{\partial y^{*}}{\partial M}<0, \frac{\partial z^{*}}{\partial M}<0$. Therefore, the change in parameter $M$ will affect the decision-making behaviors of the three parties under the premise that the other parameters remain unchanged.

A. When $z>\frac{a_{1}+a_{2}}{y(M-m)}$, the local government will choose to implement the fiscal policy. Increasing $M$ leads to a decrease in $y^{*}$ and $z^{*}$. Thus, $z=\frac{a_{1}+a_{2}}{y(M-m)}$ moves inward, leading the probability of $z>\frac{a_{1}+a_{2}}{y(M-m)}$ to increase. Therefore, the possibility that the local government chooses to implement the fiscal policy will increase.

B. When $x>\frac{b}{z(N-n)}-\frac{n+b}{N-n}$, the polluting enterprise will accept the fiscal policy and choose third-party control. Increasing $M$ leads to an increase in $x^{*}$ and a decrease in $z^{*}$. The change in $\mathrm{M}$ does not affect the position of $x=\frac{b}{z(N-n)}-\frac{n+b}{N-n}$. Therefore, the possibility of the polluting enterprise choosing to accept the fiscal policy will be unchanged.

C. When $x>\frac{c}{y(R-r)}-\frac{r+c}{R-r}$, the third-party enterprise will accept the fiscal policy and increase the supply for third-party control. Increasing $M$ leads to an increase in $x^{*}$ and a decrease in $\mathrm{y}^{*}$. The change in $M$ does not affect the position of $x=\frac{c}{y(R-r)}-\frac{r+c}{R-r}$. Therefore, the possibility of the third-party enterprise choosing to accept the fiscal policy will decrease.

In conclusion, the increase in M is conducive to the convergence to the ideal ESS (implementation, acceptance and acceptance). The decrease in M is not conducive to the convergence to the ideal ESS. Therefore, improving the local government's benefit from third-party control is conducive to promoting third-party control.

\section{Conclusions and Policy Implications}

\subsection{Conclusions}

This paper establishes a tripartite evolutionary game model of third-party environmental pollution control, studies the mechanism of fiscal policy by analyzing the replicator dynamics, evolutionary stability strategies and numerical simulation, and discusses the influences of other parameters on the implementation of third-party environmental pollution control. The conclusions are described as follows:

(1) When the local government implements a fiscal policy for third-party environmental pollution control, the decisions of the local government, the polluting enterprise and the third-party enterprise influence each other. The choices of third-party governance made by the polluting enterprise and the third-party enterprise are affected by the fiscal policy. 
(2) The strength of the fiscal policy, the risks to the polluting enterprise and the third-party enterprise, and the benefit to the local government from third-party control affect the speed of the convergence of the local government, the polluting enterprise and the third-party enterprise towards the ideal ESS (implementation, acceptance, acceptance). Improving the strength of the fiscal policy, reducing the risks to the polluting enterprise and third-party enterprise, and improving the benefit to the local government are conducive for promoting third-party environmental pollution control.

\subsection{Policy Implications}

According to the above mentioned conclusions, to promote third-party environmental pollution control in China, this paper offers fiscal policies and suggestions from the following perspectives.

\section{(1) Formulate fiscal policies for third-party environmental pollution control}

The Chinese government could formulate further fiscal expenditure and revenue policies for third-party environmental pollution control.

Regarding fiscal expenditure policies, it is suggested to establish special financial funds and carry out the policy of "Awards replace subsidies". Firstly, international, national and provincial financial funds could be set up. Governments of different countries could cooperate to support third-party enterprises for participating in international third-party control projects. Chinese central government could provide special transfer funds to third-party control projects focusing on air, water and soil pollution control. Chinese local government could arrange provincial financial funds to support third-party control projects in key industries, key pollution sources, key regions, and river basins. Secondly, subsidies for third-party control projects should be replaced by awards according to the investment scale. The incentive funds should be used during the whole life cycle of the projects, including pre-project expense awards and operation awards.

Regarding fiscal revenue policies, it is suggested to implement preferential policies for environmental protection tax, value-added tax, real estate tax and land use tax. Firstly, the environmental protection tax incentives could be increased by $10 \%$ for polluting enterprises that entrust third-party enterprises to conduct pollution control, on the basis of the current environmental protection tax incentives. Secondly, the VAT rate could be calculated and levied in accordance with the $6 \%$ VAT rate of modern service industry by creating the catalogue of value-added tax preferences for third-party control products and services in the environmental service industry. Thirdly, the real estate tax and land tax involved in third-party environmental pollution control facilities could be exempted, with reference to the exemption of real estate tax and land use tax for the units appropriated by Chinese financial departments.

(2) Implement fiscal policies in a dynamic and gradual manner

During the initial stage, the government should strengthen the implementation of fiscal policies to encourage third-party control. With the continuous improvement of the third-party control market, the implementation of fiscal policies can be gradually reduced. The fiscal policies should be adjusted and optimized according to the behaviors of the local government, the polluting enterprise, and the third-party enterprise. The optimal incentive policy system should be established to promote good interaction among the participants.

(3) Improve the market mechanism of third-party environmental pollution control

There are risks in third-party environmental pollution control due to the imperfection of the market mechanisms. Such control requires the government, the polluting enterprise, the third-party enterprise and the public to take various measures. The government should provide normative guidance by clarifying the responsibilities and setting service standards. The participants should share information by establishing good faith archives and implementing credit ratings. Strict supervision 
could be conducted to solve the moral hazard problem through strict environmental law enforcement and public participation.

(4) Assess the environmental performance of local governments

Along with social and economic indicators, environmental indicators should be included as an important part of the central government's appraisal of local governments' performance. A lifelong accountability system for ecological and environmental damage should be established, and leading officials who leave their posts should be audited. In addition, the indicators used in environmental performance assessment of local governments should be constantly updated according to the main function zoning.

\subsection{Limitations}

This study contends with several limitations. China has implemented third-party environmental pollution control for a short time and lacks the data of fiscal policies in third-party environmental pollution control. Therefore, the analysis in this paper is mainly at the theoretical level. Although evolutionary game method has achieved great success in analyzing the mechanism of policy, the model is established based on specific hypotheses and may ignore the possible changes of the local government, the polluting enterprise and the third-party enterprise by themselves. The conclusion of this paper is principally to provide reference for the government to formulate fiscal policies and other policies to promote the third-party environmental pollution control in China.

Author Contributions: Conceptualization, C.Z. and H.X.; methodology, C.Z.; software, C.Z.; validation, X.Z.; formal Analysis, C.Z. and X.Z.; writing-original draft preparation, C.Z.; writing-review and editing, H.X. and X.Z.; funding acquisition, H.X.

Funding: This research was funded by the Major Project of the National Social Science Fund of China (No. 15ZDB159), the Humanities and Social Science Project of Jiangxi University (No. JC18221), and the Science and Technology Project of Jiangxi Education Department (No. GJJ180284). We gratefully acknowledge the above financial supports.

Conflicts of Interest: The authors declare no conflict of interest.

\section{References}

1. Wang, F.; Wang, K. Assessing the Effect of Eco-City Practices on Urban Sustainability Using an Extended Ecological Footprint Model: A Case Study in Xi' an, China. Sustainability 2017, 9, 1591. [CrossRef]

2. Li, L.; Yang, W. Total Factor Efficiency Study on China's Industrial Coal Input and Wastewater Control with Dual Target Variables. Sustainability 2018, 10, 2121. [CrossRef]

3. Xie, H.; Chen, Q.; Lu, F.; Wang, W.; Yao, G.; Yu, J. Spatial-temporal disparities and influencing factors of total-factor green use efficiency of industrial land in China. J. Clean. Prod. 2019, 207, 1047-1058. [CrossRef]

4. Yang, W.; Li, L. Energy Efficiency, Ownership Structure, and Sustainable Development: Evidence from China. Sustainability 2017, 9, 912. [CrossRef]

5. Liu, K.; Lin, B. Research on influencing factors of environmental pollution in China: A spatial econometric analysis. J. Clean. Prod. 2019, 206, 356-364. [CrossRef]

6. Long, X.; Ji, X. Economic Growth Quality, Environmental Sustainability, and Social Welfare in ChinaProvincial Assessment Based on Genuine Progress Indicator (GPI). Ecol. Econ. 2019, 159, 157-176. [CrossRef]

7. Hardin, G. The Tragedy of the Common. Science 1968, 162, 1243-1248. [PubMed]

8. Tiebout, C.M. A Pure Theory of Local Expenditures. J. Polit. Econ. 1956, 64, 416-424. [CrossRef]

9. Glazer, A. Local regulation may be excessively stringent. Reg. Sci. Urban Econ. 1999, 29, 553-558. [CrossRef]

10. Sigman, H. Letting states do the dirty work: State responsibility for federal environmental regulation. Natl. Tax J. 2003, 56, 107-122. [CrossRef]

11. Liu, Q. Fiscal Decentralization, Governmental Incentives and Environmental Pollution Abatement. Econ. Survey 2013, 1, 127-132. (In Chinese)

12. Li, H.; Zhou, L. Political Turnover and Economic Performance: The Incentive Role of Personnel Control in China. J. Public Econ. 2005, 89, 1743-1762. [CrossRef] 
13. Costanza, R.; Cumberland, J.H.; Daly, H. An Introduction to Ecological Economics, 2nd ed.; The Chemical Rubber Company Press: Boca Raton, FA, USA, 2014.

14. Zhou, L. A study on promotion modes of local officials in China. Econ. Res. 2007, 7, 36-50. (In Chinese)

15. Liu, Y.; Martinez-Vazquez, J. Public Input Competition under Stackelberg Equilibrium: A Note. J. Public Econ. Theory 2015, 17, 1022-1037. [CrossRef]

16. Rauscher, M. Economic Growth and Tax-competition Leviathans. Int. Tax Public Finan. 2005, 12, 457-474. [CrossRef]

17. Abdessalam, A.H.; Kamwa, E. Tax Competition and Determination of the Quality of Public Goods. Econo. Open-Access 2014, 8, 1-20. [CrossRef]

18. Xu, X.; Li, H.; Wang, M. Regional integration, economic growth and political promotion. Economics (Quarterly) 2007, 4, 1075-1096. (In Chinese)

19. Oates, W.E.; Schwab, R.M. The Window Tax: A Case Study in Excess Burden. J. Econ. Perspect. 2015, $29,163-180$. [CrossRef]

20. Xu, S.; Lu, Y.; Chen, P.; Gao, J. Research on the current situation and development trend of financial expenditure for environmental protection. Ecological Economy 2018, 34, 71-76. (In Chinese)

21. Cui, Y.; Liu, X. Game analysis of environmental pollution control strategies between local governments in China based on the perspective of government social welfare goals. Theory Reform 2009, 6, 62-65. (In Chinese)

22. Zhang, Z.; Zhao, W. Research on Financial Pressure, Poverty Governance, and Environmental Pollution in China. Sustainability 2018, 10, 1834. [CrossRef]

23. Lenka, S.; Tatiana, K.; Jiřina, J. Bridging theories on environmental governance: Insights from free-market approaches and institutional ecological economics perspectives. Ecol. Econ. 2010, 69, 1368-1372.

24. Vatn, A. Environmental Governance-From Public to Private? Ecol. Econ. 2018, 148, 170-177. [CrossRef]

25. The Third Plenary Session of the 18th Central Committee of the People's Republic of China. Decision of the CPC Central Committee on Several Major Issues Concerning Comprehensively Deepening Reform. Available online: http://www.gov.cn/jrzg/2013-11/15/content_2528179.htm (accessed on 12 November 2013).

26. General Office of the State Council of China. Opinions on Implementing Third-Party Environmental Pollution Control. Available online: http://www.gov.cn/xinwen/2015-01/14/content_2804015.htm (accessed on 14 January 2015).

27. Cao, L. Market players, performance distribution and third-party treatment of environmental pollution. Reform 2017, 10, 95-104. (In Chinese)

28. Li, C.; Mao, S. The structural obstacles to the third-party treatment of environmental pollution in China. Environmental Protection 2018, 46, 46-50. (In Chinese)

29. Ge, C.; Cheng, C.; Dong, Z. Problems and development ideas of third-party environmental pollution control. Environ. Prot. 2014, 20, 28-30. (In Chinese)

30. Marshall, A. The Principles of Economics; Macmillan: London, UK, 1890.

31. Pigou. The Economics of Welfare; Macmillan Co: London, UK, 1920.

32. Paul, S.A. The Pure Theory of Public Expenditure. Rev. Econ. Stat. 1954, 36, 387-389.

33. Nash, R. Wilderness and the American Mind; Yale University Press: New Haven, CO, USA, 2001.

34. Cioc, M. The Rhine: An Eco-Biography, 1815-2000; University of Washington Press: Washington, WA, USA, 2002.

35. Lee, S.Y. Drivers for the participation of small and medium-sized suppliers in green supply chain initiatives. Supply Chain Manag. 2008, 13, 185-198. [CrossRef]

36. Alm, J.; Banzhaf, H.S. Designing economic instruments for the environment in a decentralized fiscal system. J. Econ. Surv. 2012, 26, 177-202. [CrossRef]

37. Vatn, A. Markets in environmental governance-From theory to practice. Ecol. Econ. 2015, 117, $225-233$. [CrossRef]

38. Ministry of Finance, Administration of Taxation, Development and Reform Commission, Ministry of Ecology and Environment of the People's Republic of China No. 60 Notice in 2019. Available online: http://szs.mof.gov.cn/zhengwuxinxi/zhengcefabu/201904/t20190425_3234504.html (accessed on 13 April 2019).

39. Zhao, Y.; Lu, Y.; Xin, L. Practice and prospect of financial fund policy for promoting the development of environmental protection industry. China Popul. Res. Environ. 2012, S1, 20-23. (In Chinese)

40. Liu, W. Discussion on the construction path of third-party environmental pollution control industry investment fund in China. Environ. Prot. 2014, 42, 23-27. (In Chinese) 
41. Luo, J. Suggestions on the development and improvement of third-party environmental pollution control. Environ. Prot. 2014, 20, 16-19. (In Chinese)

42. Liu, C. Regulation, interaction and third-party control of environmental pollution. China Population Res. Environ. 2015, 25, 96-104. (In Chinese)

43. Friedman, D. Evolutionary Games in Economics. Econometrica 1991, 59, 637. [CrossRef]

44. Friedman, D. On economic application of evolutionary game theory. J. Evol. Econ. 1998, 8, 15-43. [CrossRef]

45. Zhang, M.; Li, H. New evolutionary game model of the regional governance of haze pollution in China. Appl. Math. Model. 2018, 63,577-590. [CrossRef]

46. Jiang, K.; You, D.; Merrill, R.; Li, Z. Implementation of a multi-agent environmental regulation strategy under Chinese fiscal decentralization: An evolutionary game theoretical approach. J. Clean. Prod. 2019, 214, 902-915. [CrossRef]

47. Du, J.; Zhao, L.; Chen, L. Study on the Evolution Game between the Governments and the Third Party Pollution Treatment companies. Sci. Technol. Manage. Res. 2015, 35, 214-218. (In Chinese)

48. Xu, R.; Wang, Y.; Wang, W. Evolutionary game analysis for third-party governance of environmental pollution. J. Amb. Intel. Hum. Comp. 2018, 5, 1-12. [CrossRef]

49. Duan, W.; Li, C.; Zhang, P. Game modeling and policy research on the system dynamics-based tripartite evolution for government environmental regulation. Cluster Comput. 2016, 19, 2061-2074. [CrossRef]

50. Xie, H.; Wang, W.; Zhang, X. Evolutionary Game and Simulation of Management Strategies of Fallow Cultivated land: A Case Study in Hunan Province, China. Land Use Policy 2018, 71, 86-97. [CrossRef]

51. Long, R.; Yang, J.; Chen, H. Co-evolutionary simulation study of multiple stakeholders in the take-out waste recycling industry chain. J. Environ. Manage. 2019, 231, 701-713. [CrossRef] [PubMed]

52. Liu, C.; Huang, W.; Yang, C. The evolutionary dynamics of China's electric vehicle industry Taxes vs. subsidies. Comput. Ind. Eng. 2017, 113, 103-122. [CrossRef]

53. Chen, W.; Hu, Z. Using evolutionary game theory to study governments and manufacturers' behavioral strategies under various carbon taxes and subsidies. J. Clean. Prod. 2018, 201, 123-141. [CrossRef]

54. Smith, J.M. The theory of games and the evolution of animal conflicts. J. Theor. Biol. 1974, 47, $209-221$. [CrossRef]

55. Ritzberger, K.; Weibull, J.W. Evolutionary Selection in Normal Form Games. Econometrica 1995, 63, 1371-1399. [CrossRef]

56. Lyapunov, A.M. The general problems of stability of motions. Moscow Fizmatgiz 1950, 55, 531-534. (In Russian) 